\title{
THE APOSTOLIC DECREE AND OUR MEAT MENU: READING ACTS 15 IN REDEMPTIVE- HISTORICAL PERSPECTIVE
}

\author{
P.H.R. (Rob) van Houwelingen \\ Theological University of Kampen, Netherlands
}

\begin{abstract}
ABSTRAK: Keputusan sidang Yerusalem mengenai umat percaya kafir bahwa mereka harus menjauhkan diri, diantaranya, dari daging dengan darah yang masih ada dan dari percabulan - secara resmi dituliskan supaya dijalankan oleh komunitas Kristen mula-mula (Kis. 15). Hal ini bergema dalam surat-surat Paulus, karena instruksi rasuli ini ditujukan kepada umat percaya non-Yahudi seperti kita. Preskripsi dari Yerusalem bukanlah hal yang merupakan insidentil, tapi berakar pada prinsip-prinsip dasar akan hidup yang dicipta, dan hal ini secara umum ditaati pada abad-abad permulaan. Tetapi, kebanyakan orang Kristen sekarang tidak merasa terbelenggu dengan aturan alkitab ini dan tidak memiliki permasalahan dengan memakan pudding darah ataupun daging steak yang mentah. Tujuan dari artikel ini adalah untuk menjelaskan, mengapa, seiring waktu, Dekrit Rasuli ini dianggap menjadi tak berlaku. Di dalam gereja dengan jumlah orang Kristen non Yahudi yang makin bertambah, keharusan dekrit ini secara sejarah penebusan telah berakhir keberadaannya.
\end{abstract}

KATA KUNCI: Sidang Yerusalem, sejarah penebusan, orang Kristen non Yahudi, makan darah, pemberhalaan. 
ABSTRACT: The decision of the Jerusalem Council concerning Gentile believers - that they had to abstain, among other things, from meat with blood still in it and from sexual immorality - was officially recorded in order to be obeyed in the early Christian communities (Acts 15). It is echoed in Paul's letters, because this apostolic instruction was intended for non-Jewish believers like us. The prescription from Jerusalem was by no means incidental, it is rooted in basic principles of created life, and it was generally observed during the first centuries. Yet, most Christians today no longer feelbound bythis biblical rule and have no problem with eating blood pudding or rare steak. The purpose of this article is to explain why, in the course of time, the Apostolic Decree was considered to have become obsolete. In a church with an increasing number of Gentile Christians, the redemptive-historical necessity of the decree had ceased to exist.

KEYWORDS: Jerusalem Council, redemptive-historical, gentile Christians, blood eating, idolatry.

\section{Introduction}

Acts 15, the chapter recording the decision from the Council in Jerusalem regarding the acceptance of Gentile (non-Jewish) Christians, may well be called one of the first decrees issued by an ecclesiastical convention. Just as in the Acts and Proceedings of a General Synod, we read about the cause leading to the decree, about the preceding deliberations and we are able to inspect an official letter which was written to make the final decree public. 
At the same time, we should take into consideration that this ecclesiastical convention, held in the middle of the first century of our era, was different in character from a present day General Synod. This was a unique moment in redemptive history, because, after Pentecost, the gospel had broken through the age-old barrier between Israel and the other nations.For there were also Gentiles who had come to faith. Did they not have to be circumcised and were they not required to observe the Law of Moses? That was the question at this ecclesiastical convention of the apostles and the elders of Jerusalem, often referred to as the Jerusalem Council. Apostles (as messengers of Jesus Christ) and elders (as eye witnesses of Jesus Christ) are irreplaceable. Therefore, only this ecclesiastical convention could appeal directly to the Holy Spirit ('It seemed good to the Holy Spirit and to us': Acts 15:28; see also verse 8).

Reading Acts 15 in redemptive-historical perspective means paying attention to the progression of God's acts in history. In Jerusalem, a decision was taken that would benefit ecclesiastical unity between Jews and Gentiles.One of the components of that decision concerned consuming meat with blood in it, or blood in general. What consequences do that have for our meat menu? Is eating black pudding, blood-sausage or rare steak forbidden? The Jehovah's Witnesses believe it is, with reference to Acts $15 .{ }^{1}$ Other Bible readers often feel uneasy about the Jerusalem decree. What does this prescription mean to us in the $21^{\text {st }}$ century? Reading in redemptive-historical perspective can improve our understanding of Acts 15.

1 See http://www.jw.org/en/publications/books/blood/blood-vital-for-life/. 
Three points will now successively come up for discussion: 1 . Why an Apostolic Decree?; 2. The far-reaching impact of the Apostolic Decree; 3. The Apostolic Decree in redemptive-historical perspective.

\section{Why an Apostolic Decree?}

The apostolic prescription, distributed from Jerusalem by letter, reads as follows: "You are to abstain from food sacrificed to idols, from blood, from the meat of strangled animals and from sexual immorality. You will do well to avoid these things" (Acts 15:29 NIV, see also verse 20).

The matter at hand is regarding, as indicated earlier, the position of the Christians from a non-Jewish background. People from many nationalities had come to faith through Paul and Barnabas' missionary work, which became apparent in the church of Antioch. Did these 'new' Christians now have to submit themselves, like the Jewish Christians, to the Torah regulations, having to be circumcised, eating only kosher food, adhering to the purification rituals, and keeping the Sabbath?

After Paul and Barnabas had explained the matter in Jerusalem, a heated discussion arose at the convention, as Luke tells us in Acts (verse 7a). But Peter was able to tell the story of what he had experienced in Caesarea, in the house of the Roman Cornelius: when he came to faith, he had received the Holy Spirit, he and all his family. In no way had God discriminated between Jews and Gentiles (verse 9). James, the brother of the Lord, supported Peter by drawing attention to a prophecy from the Book of Amos: also about Gentiles who will seek the Lord (verse 18). It was also James who 
formulated and wrote down the concept decision adopted by the meeting. ${ }^{2}$

Let us now take a closer look at the formulation of the Apostolic Decree. What James suggested was that Christians from the Gentiles were, in the translation by John of Eck, to abstain from those matters with which one becomes contaminated by idols: prostitution, the choked and from blood in general. ${ }^{3}$ The main thing is that Gentile Christians needed to make a radical break from idolatry, which brings all sorts of contamination with it (the Greek in verse 20 uses a category plural form: $\tau \tilde{\omega} v$ á $\lambda \iota \sigma \gamma \eta \mu a ́ \tau \omega v \tau \tilde{\omega} v$

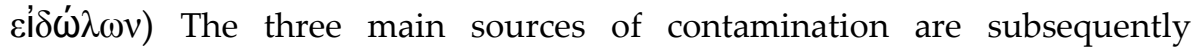

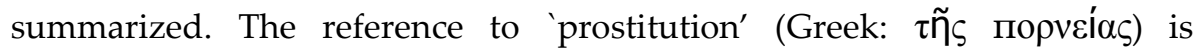
therefore not about sexual immorality in general, but about temple prostitution, which is linked to idolatry. The same applies to 'choked' meat

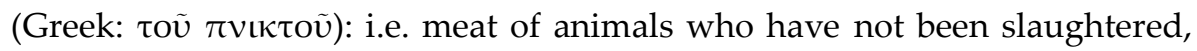
still containing the blood - meat that is still alive. ${ }^{4}$ In antiquity, eating raw,

2 More comprehensive reading: P.H.R. van Houwelingen (ed.), Apostelen. Dragers van een spraakmakend evangelie (CNT; Kampen: Kok, 2010, thirdedition 2013), 54-60. See also: Charles H. Savelle, "A Reexamination of the Prohibitions in Acts 15," Bibliotheca Sacra 161 (2004): 449-468; Markus Öhler (ed.), Aposteldekret und antikes Vereinswesen: Gemeinschaft und ihre Ordnung (WUNT 280; Tübingen: Mohr Siebeck, 2011); Pieter G.R. de Villiers, "Communal discernment in the early church," in: Pieter G.R. de Villiers(ed.), The Spirit that Guides. Discernment in the Bible and Spirituality (ActaTheologicaSupplementum 17; Bloemfontein: Sun Media, 2013), 132-155.

3 John van Eck, Handelingen. De wereld in het geding (CNT; Kampen: 2003, fourthedition 2011), 325. Regarding this, Van Eck observes that one should take the first $\kappa \alpha$ íto be explicative; in his translation this is indicated by a colon. The article used with the plural $\alpha \lambda \iota \sigma \gamma \eta \mu \alpha \dot{\tau} \alpha$ brings one to expect a list to follow, further explicating these 'matters', according to John of Eck. That list subsequently contains thrice an article plus the singular tense. The grammatical entity of verse 20 indicates that one complex of idolatrous practices is meant.

4 In his discussion of the tenth commandment, Philo criticises people who abandon themselves to senseless pleasures, such as eating meat with blood still in it, obtained through strangulation and choking (De SpecialibusLegibus IV, 122-123). David Instone Brewer thinks that the decision of Jerusalem is ambiguous, so that 'choked' could also mean the killing of babies or performing an abortion ("Infanticide and the Apostolic Decree of Acts 15," Journal or the 
bloody meat was believed to provide magical powers. It was, for example, part of the cult of Dionysus, the Greek god of unbridled vitality. ${ }^{5}$ With

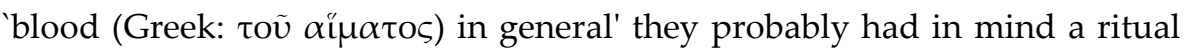
of sprinkling blood or drinking it, which was considered in pagan cultures to be a manner of obtaining the divine life power of nature.

In the letter that made public the Jerusalem Council's decree (verse 29), we first read about abstaining from eating 'food sacrificed to idols' (Greek: $\varepsilon i \delta \omega \lambda o \theta v ́ \tau \omega v)$, as a specification of the contamination by idolatry named in verse 20, followed by: blood, the meat of strangled animals and sexual immorality.The first mentioned term is also used by Paul, when he discusses the issue of sacrificial meat in 1 Corinthians 8-10. This concerns meat that has been dedicated and was eaten in the vicinity of an idol, or on the temple grounds. According to Witherington, it is a polemic term, forged within the Jewish Christianity. So it is not typically Jewish, and for this reason we can ask ourselves whether the origin of the Decree as a whole must be sought within the Jewish Bible, in the Noachic Laws (Gen. 9) or in the Mosaic Laws (Lev. 17-18). While it is true that these laws are about blood, it is not specifically about blood within the framework of idolatry. ${ }^{6}$ The

Evangelical Theological Society 52.2 (2009): 301-321). But, while this was indeed a wide spread practice in antiquity, nowhere in the New Testament do we come across warnings against this.

5 F. Graf, "Dionysus," in: Karel van der Toorn, Bob Becking \& Pieter van der Horst (eds.), Dictionary of Deities and Demons in the Bible. Second, extensively revised Edition (Leiden: Brill, 1999), 252-258.

6 Ben Witherington III, “Not so Idle Thoughts about Eidolothuton,” Tyndale Bulletin 44.2 (1993): 237-254. "The Decree in Acts 15 is about Gentiles refraining from meals and immorality in pagan temples, not about them keeping a modicum of Jewish, or Noachic food laws"; A.J.M. Wedderburn, "The 'Apostolic Decree': Tradition and Redaction,"Novum Testamentum 35. 4 (1993): 362-389. Regarding motivation and meaning of specific prohibitions to eat blood in the Old Testament, see the contribution by Versluis in this volume. 
apostolic prescription was apparently not just meant as a unilateral concession to the Jews, as has been frequently claimed. ${ }^{7}$ The decision taken at the Jerusalem Council, however, does affect the basic principles regarding created life: blood, the bearer of life of both humans and animals, belongs to God the Creator. That was, indeed, the deep conviction of the people of Israel. No wonder that the Jews objected violently when Jesus, who had presented Himself as the Bread of life, claimed that true and everlasting life is nourished by eating his body and drinking his blood (John 6:52-59). After an exhaustive discussion, Roland Deines reaches the conclusion that "the Decree obliges Gentile Christians to live a life according to the most basic elements of God's order of creation". And so it must follow, says Deines, 'that this does not denote submission to the Torah (notwithstanding that for Luke, as also for Philo, there is no contradiction between the creation order and the Torah), but it is an expression of their faith and their relation to the God of Israel, who has called them in Jesus to be his people" ${ }^{8}$

If we try to analyse what is happening here, then the Early Church is being confronted, in her development, with a concrete problem that has not

7 An exhaustive refutation was presented by E.A. de Boer, "Ethiek en de Acta van Jeruzalem. Een exegetisch onderzoek naar de betekenis van het besluit van Handelingen XV," in: Almanak Fides Quadrat Intellectum 1980 (Kampen: Zalsman, 1980), 139-168. For a more concise treatment, see: Jakob van Bruggen, Paul. Pioneer for Israel's Messiah (Phillipsburg: P\&R, 2005), 51-55.

8 Roland Deines, "The Apostolic Decree: Halakhah for Gentile Christians or Concession to Jewish Taboos?" in: Acts of God in History. Edited by Christoph Ochs \& Peter Watt (WUNT 317; Tübingen: Mohr Siebeck, 2013), 121-188 [186]. Something similar, but from another perspective, is argued by David Flusser\& Shmuel Safrai: "Das Aposteldekret und die Noachitischen Gebote," in: Edna Brocke\& Hans-Joachim Barkenings (eds.), Wer Tora mehrt, vermehrt Leben: Festgabe für Heinz Kremers zum 60.Geburtstag (Neukirchen-Vluyn: Neukirchener Verlag, 1986), 173-192. According to the rabbis, the Torah applied exclusively to Jews, whereas God requires of Gentiles that they maintain the universal principles, generally applicable and intended for all humanity. 
come up before in history, so that they could not fall back on existing legislation. How shall they deal with believers who are not from Israel but from other nations? This question is raised in the mother church in Jerusalem by the young church of Antioch. A responsible solution is what the convening apostles (with Peter as spokesman) and elders (with James as spokesman) are looking for - taking note of the redemptive acts of God towards Gentiles, in line with the prophetic testimony of the Scriptures and conscious of the guidance of the Holy Spirit. Well then, the Messiah of Israel is the Saviour of the world. Through Jesus Christ, believers from all nations belong directly (thus, without becoming Jewish) to the God of Israel and, through faith, share in His promises. As Amos had prophesied, the name of the LORD has been proclaimed over them, too (Acts 15:15-18, referring to Am. 9:11-12 LXX). This is why, according to the Jerusalem Council, they can be accepted as full members of the Christian worldwide Church.

\section{The far-reaching impact of the Apostolic Decree}

How important this Jerusalem decree was, becomes clear from the fact that it was sent by means of an official letter to Antioch, the church that had brought the matter to the table. Two authoritative delegates, chosen especially for that purpose, Judas Barsabbas and Silas, were sent along with this epistle to read it out loud, explain it and take time to discuss the consequences with the church (Acts 15:22 and 30-33).

On their next missionary journey, Paul and Barnabas passed on the Jerusalem decree to the churches visited by them, and charged all Christians to uphold it (Acts 16:4). This applies at least to the beginning of their 
journey, to the South of Asia Minor, but probably also to the continuation of their travels, when they had crossed over to Europe. In his first letter to the Thessalonians, written during this second missionary journey, Paul clearly alludes to the Jerusalem decree: "It is the will of God that you lead a holy life: that you refrain from sexual abuse" (1 Thes. 4:2-3; cf. 5:22).

When Paul visited Jerusalem again at the end of the third missionary journey (the meeting of apostles and elders described in Acts 15 had then taken place approximately ten years earlier), he is given a warm reception by James and the elders. The report of his mission among the peoples of the world is reason for them to exalt God. At the same time, James and the elders literally quote the decree for which they themselves were responsible: "As for the Gentile believers, we have written to them our decision that they should abstain from food sacrificed to idols, from blood, from the meat of strangled animals and from sexual immorality" (Acts 21:25).

Paul deals with a concrete matter of eating food sacrificed to idols in his first letter to the Corinthians (1 Cor. 8-10), but strangely enough he does not write anything there about eating meat with blood in it or about blood in general. ${ }^{9}$ With his directions for the daily practice of the Christians of Corinth, where eating and drinking is concerned, he seems to move along

9 I leave the relation with what Paul has to say to the Corinthians aside for further consideration. An interesting approach that takes into account Paul's rabbinical line of arguing, is that he develops the decision of Jerusalem to fit the specific situation of the Corinthians. How should one act in doubtful cases that come up in every day practice, for example, when Christians buy meat at the market or are seated at the table of a pagan host? Thus says Peter J. Tomson, Paul and the Jewish Law. Halakha in the Letters of the Apostle to the Gentiles (Assen/Maastricht 1990), 187-220.However it may be, "Die Entscheidung auf dem Apostelkonvent im Jahr 48 war für Paulus grundsätzlich akzeptabel" (Eckhard J. Schnabel, Urchristliche Mission (Wuppertal: Brockhaus, 2002), 977). 
the lines of the Apostolic Decree. In lists of condemnable behaviour from other letters of Paul, we more than once come across the combination of idolatry, adultery and other forms of licentiousness, in which this decree still resounds (see for example Gal. 5:19-21).

More traces can be found in the New Testament of what, according to Acts 15, was agreed upon in Acts 15. John concludes his first letter with the remarkable plea: "Dear children, keep yourselves from idols" (1 John 5:21). In addition, the letters to the seven churches in the Book of Revelation twice contain a celestial warning against a combination of eating pagan sacrificial meat and committing sexual offences. Thus it is said to the church of Pergamum: "There are some among you who hold to the teaching of Balaam, who taught Balak to entice the Israelites to sin so that they ate food sacrificed to idols and committed sexual immorality" (Rev. 2:14). And the church of Thyatira gets to hear the following: "I have this against you: You tolerate that woman Jezebel, who calls herself a prophet. By her teaching she misleads my servants into sexual immorality and the eating of food sacrificed to idols" (Rev. 2:20).

Towards the end of the first century, the ecclesiastical rule of life was: "Now concerning food, bear what you are able, but in any case keep strictly away from meat sacrificed to idols, for it involves the worship of dead gods" (Didache 6:3). ${ }^{10}$ Just as in the recorded Jerusalem decree, eating 'meat of idols'

10 Explanation of this key text from the Didache can be found in: Aaron Milavec, "When, Why, and for Whom Was the Didache Created? Insights into the Social and Historical Setting of the Didache Communities," in: Huub van de Sandt (ed.), Matthew and the Didache. Two Documents from the Same Jewish-Christian Milieu?(Assen: Royal Van Gorcum/Minneapolis: Fortress Press, 2005), 63-84.CF. Van Houwelingen, Apostelen, 225-227. 
(cf. Acts 15:29) is typical of the pagan cult, where one worships, paradoxically, bloodless gods without soul.

In his Church History (V 1, 26), Eusebius cites a letter from the Gallic churches that must have been written about AD 177-178, in which a certain Biblis is mentioned. She herself, together with others, having renounced the Christian faith upon torture, later came to her senses and contradicted the accusations of cannibalism at the Lord's Supper with the words: "How would such men eat children, when they are not allowed to eat the blood even of irrational animals?" From then on she professed to be a Christian, says Eusebius, and so she joined the ranks of the martyrs.

These references make it clear that the Jerusalem decree was a specific regulation, concerning the position of Gentile Christians, essential for the development of the Christian church. Many testimonies from the first centuries confirm that Christians from other than Jewish backgrounds adhered to the decision of Jerusalem.Origen cites the decree in his comment on Romans 2:13 and considers it binding still for the Christian church of his days. ${ }^{11}$ That Christians must refrain from blood, we read explicitly in writings by other early church fathers, such as Clemens of Alexandria and Tertullian. According to Richard Bauckham, the worldwide spreading of this decree cannot be explained other than that all the leaders of the early church, including James, Peter and Paul, had fully endorsed it.12 For the Jewish

11 Jürgen Wehnert, Die Reinheit des 'christlichen Gottesvolkes' aus Juden und Heiden. Studien zum historischen und theologischen Hintergrund des sogenannten Aposteldekrets (Göttingen: Vandenhoeck \& Ruprecht, 1997), 206-207.

12 Richard Bauckham, "James and the Jerusalem Church," in: Richard Bauckham (ed.), The Book of Acts in Its First-Century Setting. Volume 4: Palestinian Setting (Grand Rapids: Eerdmans, 1995), 415-480 [462-467]. See also Tomson, Paul and the Jewish Law, 177-186; Markus Lang, "Die 
Christians, the decree had more of an indirect meaning, namely that they were called to accept all Gentile Christians as full brothers and sisters.

\section{The Apostolic Decree in redemptive-historical perspective}

There can, therefore, be no talk of an incidental measure. The Jerusalem Council's decree has been taken with the full authority of the apostles and the elders. They called their prescriptions absolutely necessary (Acts 15:28). Nowhere do we read that this regulation expired. Yet these days we, as Christians, do not feel ourselves tied to it; although not everyone is partial to blood sausage, we have no objections on principle against eating it. The only significant exception is, of course, the Jehovah's Witnesses, who, as a matter of fact, even call on Acts 15 to reject every form of blood transfusion. That we do not follow them in their rejection of blood sausage, and do not make fundamental objections against something like rare steak, has at least five reasons. Reading in redemptive - historical perspective leads to hermeneutical awareness.

a. The Jerusalem decree was issued in a unique redemptive-historical situation, where two Christian cultures - an older one (represented by the mother church in Jerusalem) and a younger one (represented by the new church of Antioch) - had to learn to live with one another, the younger culture by taking into account the older one, the older by fully accepting the younger. 
b. The Jerusalem decree consists of a range of conditions, where the first mentioned always has a connection to idolatry, with the order of the following elements varying, so that these can be considered to be an explication of the former. In other words: it was about keeping the Gentile Christians as far away from idols as possible and connecting them to the God of Israel in a recognizable manner.

c. With a view to the Jerusalem Council at which this decree was issued, we can say that it has as underlying reason that Gentile Christians do not need to become Jews, but may also not remain part-pagan. Therefore it can be demanded of them that they break radically with paganism. All idol worship, which can be expressed in ritual prostitution, eating raw, bloody meat and drinking blood, is pagan.

d. The so-called Western Text of Acts omits one component from the Jerusalem decree ('the choked' is missing) and adds, in verses 20 and 29, the negative form of the Golden Rule: "do to others what you would have them do to you" (Mat. 7:12; Luk. 6:31). In this way the decree, already early on in the Christian tradition, seems to have been adapted to a new situation and developed into a generally practicable rule of life. ${ }^{13}$

e. Regarding the eating, or not eating, of sacrificial meat: according to Paul, this is ultimately a question of conscience (Rom. 14:5; 1 Cor. 8:7, 10, 12 and 10:25, 27-29), where brotherly love enables someone to abstain from his or her 'right'. But the motto remains, in the line of the

13 Richard I. Pervo, “Excursus: The Apostolic Decree," in: Acts (Hermeneia; Minneapolis: Fortress Press, 2009), 376-378. "The history of the text indicates its continuing vitality" [378]. 
Jerusalem decree: "Flee from idolatry" (1 Cor. 10:14). Participating in sacrificial meals brings people into contact with demons, says Paul; they should rather be content with celebrating the Lord's Supper.

Meanwhile, the Christian church is now centuries further. While the purpose of the Jerusalem decree was to keep Gentile believers safe from the temptation of idolatry by marking the boundaries, the social and religious context changed. Christianity was proclaimed state religion under Emperor Constantine, so that the pagan temples became more and more obsolete, and with it, the daily threat of falling back into idolatry. This is also why, today, eating blood sausage or rare steak is no longer surrounded by an air of paganism.

Besides, in our present times we no longer feel a natural gap between believers from Jewish and non-Jewish backgrounds. ${ }^{14}$ Already in the days of Augustine, when the Christian church consisted of non-Jewish Christians, anyone adhering to the food-prescriptions was laughed at, so common was the conviction that evil is in the sin and not in consuming daily nourishment. ${ }^{15}$ Later on the Augsburg Confession (1530), Article 28, also assumes that nobody keeps the Jerusalem decree any longer, and that this is not a sin; that was also the position taken by Luther. ${ }^{16}$ Today, Jewish

\footnotetext{
14 Here the question arises whether we have not gone to the other extreme by erasing every distinction. In our times, we might shrink a little more from bloodshed.

15 Augustine, Contra Faustum XXXII 13, with reference to the Apostolic Decree.

16 As an indication of how impossible and unnecessary it is to observe the Jerusalem decree, Luther writes with great irony: "Now if we want to have a church that conforms to this council, ... we must teach and insist that henceforth no prince, lord, burgher, or peasant eat geese, doe, stag, or pork cooked in blood... And burghers and peasants must abstain especially from red
} 
Christians are no longer in the majority, but form a small minority. As far as ecclesiastical integration is concerned, we sooner have difficulty accepting a Jewish believer than believers from a heathen background. Today the message should bethat the Christian church may not forget its Jewish heritage.It started in Jerusalem!

From the foregoing discussion it is clear that the Apostolic Decree, in a church which then consisted for the greater part of Gentile Christians, was considered obsolete in the course of time.This is understandable, because the redemptive-historical necessity of the decree had ceased to exist. That is why we, as (Western) non-Jewish Christians of the $21^{\text {st }}$ century, are no longer tied to it. ${ }^{17}$ Nevertheless, the redemptive-historical value of the Jerusalem decree cannot remain undiscussed in the dialogue between the church and Israel. We would do well to continue to take the message resounding from Acts 15 to heart. Being a Christian still means that every follower of Jesus Christ is welcome to the God of Israel, regardless of background, Jew or not. But Christians must break with a life without God, therefore with all forms of godlessness, and from now on live according to God's will (1 Pet. 4:2-3). As for eating meat, the same applies as for all foods, that what God created is to be received with thanksgiving by those who believe (1 Tim. 4:3). The essence of the Apostolic Decree, which can also be honoured in other missionary

\footnotetext{
sausage and blood sausage" (Von den Konziliis und Kirchen, Weimarer Ausgabe 50, 526). Apparently Luther's irony escaped the Jehovah's Witnesses, because they use this quote to support their objection against using blood (see footnote 1).

17 Prosman suggests otherwise: according to him the apostles actualised and concretised the legislation from Leviticus concerning sexuality (A.A.A. Prosman, "Homosexualiteit en hermeneutiek: over het gezag van Leviticus 18 en 20 in relatie tot Handelingen 15," Theologia Reformata 56.3 (2013): 225-244). He does not explain, however, why the Jerusalem decree already became obsolete relatively early in church history.
} 
contexts, regards upholding the religious antithesis in a world full of idols. To put it differently: Christ is enough; a connection of faith with Him leads to a different life attitude and life vision. ${ }^{18}$

This Apostolic prescription from Acts 15 is not to be regarded separately. It tells us something about the way the church of Jerusalem handled its context, and concerning the motivation of the apostles and elders. ${ }^{19}$ That, on the whole, should guide us in our current context, also when making ecclesiastical agreements and individual choices in ethical areas. ${ }^{20}$ So it remains important that different 'blood groups' accept each other in the church as full Christians. It was possible even to bridge the gap between Jews and Gentiles: two totally different environments were forged by the blood, the crucifixion, of Jesus Christ (Eph. 2:11-18).

There will always be differences of opinion between Christians. No rule can change that. What is on our menu and what to participate in, and what not, is a question of conscience, for which we must all give account to God (Rom. 14:1-12). Christians need not burden themselves with regulations

18 In the preceding, the reflections have continually been from our Western context. The Jerusalem decree worked out in different missionary contexts is provided by C.J. Haak, Metamorfose. Intercultureel begeleiden van kerken in een niet-christelijke omgeving (Zoetermeer: Boekencentrum, 2002), 65-72.

19 Taking into account the reactions of outsiders, for example, is an important ethical motif in the New Testament. On this, see Andrie B. Du Toit, "Sensitivity towards the reaction of outsiders as ethical motivation in early Christian paraenesis," HTS Theological Studies 68.1 (2012), 7 pages, http://dx.doi.org/10.4102/hts.v68i1.1212.

20 From a systematic theological perspective, the reformed tradition has always emphasized that, without general revelation, special revelation loses its connectedness with the whole cosmic existence and life. Furthermore, obedience to the Scriptures is not an aim in itself; it is reacting to the God who reveals himself. See Herman Bavinck, Reformed Dogmatics, Volume 1 (John Bolt, editor \& John Vriend, translator; Grand Rapids: Baker Academic, 2003), chapter 10 12 [301-385]. 
concerning what to eat and drink (Col. 2:16). But one can abstain from something on a voluntary basis.In all decisions, we must take into loving consideration our brothers and sisters, those close by (our own church) as well as far off, keeping in mind the principle of the Golden Rule in the positive form: do to others what you would have them do to you. Thus, we have seen the enduring meaning of the Jerusalem decree, read in redemptive-historical perspective. 